Page 1 of 16

\title{
1 Epidemiological Characteristics of Early COVID-19 Case Outbreaks in Indonesia
}

2

Abu Bakar ${ }^{1,3}$, Triyono Indrasiwi Kuncoroaji ${ }^{2}$, Andy Lee ${ }^{3}$, Shih-Chieh Lee ${ }^{3 *}$, Valendriyani Ningrum ${ }^{{ }^{*}}$

1. School of Dentistry, Baiturrahmah University, Kuranji, Padang, Indonesia

2. College of Management, Da-Yeh University., Dacun, Changhua, Taiwan, Republic of China

3. Department of Food Science and Biotechnology, Da-Yeh University., Dacun, Changhua, Taiwan, Republic of China

*Equal Contributing corresponding Author

1. Prof. Shih-Chieh Lee

Department of Food Science and Biotechnology, Da-Yeh University

No. 168, University Road, Dacun, Changhua, 51591, Taiwan, Republic of China

Telp: +88648511888 ext.4262,2280

Fax: +88648511666

Email: toronto.jacklee@gmail.com or slee@mail.dyu.edu.tw

2. Dr. Valendriyani Ningrum

School of Dentistry, Baiturrahmah University, Jl. By Pass, KM. 15, Kuranji, Padang, Indonesia

Telp: +628 5228278088

Email: valend@fkg.unbrah.ac.id or valend888@gmail.com

\section{Abstract}

The initial outbreak of COVID-19 was first reported in Wuhan (China) during the latter part of December 2019. Indonesia has the fourth-largest population globally and reported the country's first case of the virus on $2^{\text {nd }}$ March 2020. The World Health Organisation (WHO) in addition to several neighbouring provinces and educational institutions within the region began questioning the Indonesian government upon the initial case reported. The objective of this study was to describe the epidemiological characteristics of the COVID-19 outbreak in Indonesia during March 2020. The data were collected from Indonesian government databases and non-government organisations (NGOs). The data were analysed using Microsoft Office 2019 (Excel) and Adobe Illustrator 2017 software, was used in drawing the map 
1 depicting the distribution of COVID-19 in Indonesia. As at 31 ${ }^{\text {st }}$ March 2020, a total of 1,528 people in 2 Indonesia have been infected by COVID-19, in addition to 136 mortalities (CFR of 8.9\%). Jakarta, as the principal capital of Indonesia, quickly has become the epicentre of the virus since this period. Most patient cases were attributed to those aged between 31 and 70 years (72.64\%), with male patients $(64.93 \%)$ representing the highest incidence of cases compared to female patients (35.07\%). The number of ventilating machines was 3,326, with hospital numbers at 859. The distribution of cases depicting COVID19 was mainly seen in urban areas compared to rural areas. Males compared to females, are at a higher risk of contracting COVID-19, including those aged below 30, between 30 and 60 or above. Indonesia also has the highest case fatality rate (CFR) with respect to mortalities in Southeast Asia and has the second-highest CFR globally. Similarly, while the number of ventilator machines as at $31^{\text {st }}$ March 2020 were sufficient in meeting the growing number of COVID-19 cases in the country, it is possible that the government may need to increase the number of ventilators if the cases continue to escalate.

Keywords: Confirmed cases, case fatality rate, province, age, gender.

\section{4}

\section{Introduction}

The Coronavirus virus commonly referred to as "COVID-19", was first sighted in Wuhan (China) in December 2019 based upon several patients diagnosed having pneumonia from the Huanan Animal Wet Market area [1]. The virus over the next few months rapidly spread infecting other countries globally. The World Health Organisation (WHO) initially reported the situation and the spread of the virus at 10:00 CET on the $27^{\text {th }}$ March 2020, in which a total number of COVID-19 cases reported was 509,164. Sixteen days before this date, $\mathrm{WHO}$ announced the nature of the situation of the disease as a global pandemic [2]. As at $31^{\text {st }}$ March 2020, 200 countries from all regions of the globe (Asia, Africa, America, Europe, and Oceania) confirmed the population of these countries being infected by the virus. It was also reported that 37,820 people (4.81\%) had died from contracting the virus with 165,659 people $(21.1 \%)$ having recovered.

The Chinese Centre for Disease Control and Prevention published the characteristics associated with the epidemiology. On $11^{\text {th }}$ February 2020, 44,672 (62\%) of 72,314 cases had been confirmed and tested positive for COVID-19. Of the confirmed cases, 38,680 (87\%) of those people infected were aged between 30 and 79. The spectrum of the disease ranged from mild (81\%) to severe (14\%) and critical (5\%). The case fatality rate (CFR) was $2.3 \%$ (1,023 of 44,672 confirmed cases) with $14.8 \%$ of patients above the age of 80 years, and $8.0 \%$ of patients aged between 70 and 79 years [3]. Italy, at that time, reported the highest incidence of deaths mainly detected among older, male patients also having multiple comorbidities [4]. 
Numerous studies have reported that the most common cases were those aged between 30 and 79 years [3] with the median age ranging between 49 and 59 years [1] [5-6].

Regarding the disease, the clinical features consist of fever, cough, myalgia, headache, and diarrhoea with less common symptoms including sputum production, dyspnoea, leucopenia and lymphopenia during the onset of the disease [1] [5] [7-9]. The clinical types of the illness are separated into three types, namely, mild, severe and critical as mentioned earlier. Symptoms of the mild type include non-pneumonia or mild pneumonia, while patients diagnosed with the severe type include dyspnoea, respiratory frequency $\geq$ $30 / \mathrm{min}$, blood oxygen saturation $\leq 93 \%$, the partial pressure of arterial oxygen to the fraction of inspired oxygen ratio $<300$, and/or lung infiltration $>50 \%$ within the first 24 to 48 hours. The critical type of COVID-19 consists of symptoms such as respiratory failure, septic shock, and/or multiple organ dysfunction or failure [10]. Some patients have companion diseases, such as diabetes, hypertension, and cardiovascular disease [1] [5-6] [8]. Presently, the transmission of the virus is continuing at an alarming rate of infection and relies on the effectiveness of current control measures in detecting the disease. In preventing the disease from spreading, risk-mitigating and control measures and behaviours have been adopted, however, given the absence of antiviral drugs or vaccines, control of the disease depends on the rapid testing, detection and controlling the sources of infection thereby protecting the exposure and susceptibility of people to the virus and eliminating the transmission and isolation of symptomatic cases [10-11].

Since the outbreak of the disease, Indonesia has come under increasing attention and pressure, given the rapid outbreak of COVID-19 in the country [12-13]. Other Southeast Asian countries like Malaysia, Singapore and Thailand have also announced the first cases of COVID-19 in January 2020. Between January and February, Indonesian authorities had not announced nor mentioned any cases of the virus, which many countries, including WHO, were quite sceptical until the first case was announced on $2^{\text {nd }}$ March 2020.

Indonesia is located in Southeast Asia, having a population of around 270 million and is currently the most populated country within the region with the fourth-largest population globally. The characteristics of the Indonesian population, predominantly Muslim, adhere to the teachings of Islam, which has also contributed towards the spread of the disease and the number of cases in the country. The Muslim population in Indonesia have a tradition of shaking hands, worshipping in congregations and groups, visiting each other, and conducting recitation or prayers by gathering in one place. To the best of our 
1 knowledge, this is the first study that describes the characteristics of confirmed COVID-19 cases in

2 Indonesia in addition to the nation's CFR. The availability and accessibility of hospitals and ventilators in 3 each province are also examined and compared to current reported confirmed cases.

\section{2. Method}

5

\section{Data collection}

The data were obtained from the official COVID-19 website of Indonesia's Central Government authority [14]. Databases compiled by government provinces, namely, Jakarta, Banten, West Java, Central Java and East Java confirmed more than 50 cases of COVID-19 [15-17]. Data were also obtained from nongovernment organisations (NGOs) and via https://kawalcovid19.id/ [18]. The data from kawalcovid19.id were collected by volunteers reporting quite detailed information compared to the information announced and reported by the Indonesian authorities. The positive cases reported depicted patients who had tested positive via polymerase chain reaction methods.

The CFR of COVID-19 cases in Indonesia was also compared to other countries in the Southeast Asian region and with countries globally. Also described was the situation regarding hospitals, the availability of ventilators and mortalities due to COVID-19.

\section{Data analysis}

The data were analysed using Microsoft Office 2019 (Excel) in recording the daily number of reported cases during March 2020, and the characteristics of people (age and gender) who tested positive for COVID-19. The COVID-19 distribution of cases in Indonesia, namely across five provinces in Java is illustrated using Adobe Illustrator 2017 software.

\section{Results}

The first reported COVID-19 case in Indonesia was announced on $2^{\text {nd }}$ March 2020, a female patient who had come into contact with people of Japanese origin in Jakarta; the second case was the woman's mother. The Indonesian authority, however, did not announce any new cases until three days following the reporting of these two cases. From $10^{\text {th }}$ March, 13 new cases were reported; on $15^{\text {th }}$ March the number of new cases quickly rose to 117 , and from $23^{\text {rd }}$ March the daily number of new cases exceeded 100 (see Figure 1). As at $31^{\text {st }}$ March, the total number of cases reported was 1,528, with 81 (5.3\%) patients having recovered and 136 deaths (CFR: $8.9 \%$ ). 
1 Figure 2 shows that the number of cases has spread to 30 provinces in Indonesia. Jakarta, as the capital of 2 Indonesia, had become the epicentre of COVID-19, having the highest number of confirmed cases (747 cases, 48.8\%), followed by its neighbouring provinces: West Java (198 cases, 15.7\%), Banten (143 cases, $11.3 \%$ ) Central Java and East Java, both reporting 93 cases (7.3\%). The total number of cases reported in Java Island included Yogyakarta with 1,297 reported cases (84.8\%). Outside of the island, several provinces reported over ten confirmed cases, namely South Sulawesi (50 cases, 3.2\%), East Kalimantan (20 cases, 1.3\%) and North Sumatra with 19 cases (1.2\%) (see Figure 2). The distribution map shows the large cities in the Java Island such as Surabaya, Semarang, Bandung and Jabodetabek (Jakarta, Bogor, Depok, Tangerang, and Bekasi) being at a higher risk compared to rural areas (see Figure 3).

The distribution of COVID-19 according to age and gender in Indonesia had not been announced until $14^{\text {th }}$ March 2020. The most recent data reported that 38 males (55\%) and 29 females (42\%) had been infected by COVID-19, with two positive cases unannounced. According to the distribution of age, people who had been infected were mostly aged between 40 and 59 years (31 cases, 44.9\%). Figure 3 displays further data. Due to the lack of transparency surrounding the data collected from Indonesian authorities, several volunteers helped to collect the data from academics, medical personnel, and other NGOs by developing a web-enabled database to depict the characteristics of COVID-19. Figure 3 presents the distribution of COVID-19 according to age and gender. The total number of cases of male patients (298 cases, 64.93\%) was higher compared to female patients (161 cases, 35.07\%). Table 1 displays the distribution of cases according to age.

Table 2 shows that Jakarta had the highest number of mortalities at 83 (CFR: 11.1\%) followed by West Java with 21 deaths (CFR: 10.6\%), East Java with eight deaths (CFR: 8.6\%) and Central Java with seven deaths (CFR: 7.5\%). Outside Java, the first reported case was in Bengkulu, which was the only confirmed case in the province; thus, the CFR was 100\%. Similarly, in West Papua, there had been one reported mortality from two confirmed cases (CFR: 50\%). The data regarding hospitals and the number of ventilators in each province were obtained from a current report depicting the situation concerning the COVID-19 outbreak from the Indonesian authority. The hypothesis surrounding the number of ventilators was based on the number of confirmed cases as at $31^{\text {st }}$ March 2020, indicating that the number of ventilators was sufficient across all provinces. Nevertheless, the possibility remains that if more cases are reported, the number of ventilators may not be adequate. 
Page 6 of 16

1 During this period, the CFR in Indonesia was the second-highest globally, followed by Italy (CFR: 11.7\%) 2 where the number of mortalities was 12,428 from 105,792 cases. In Southeast Asia, the CFR in Indonesia was the highest, followed by the Philippines with 2,084 confirmed cases and 88 deaths (CFR: 4.2\%), and Malaysia, having the most cases $(2,766)$ but with fewer mortalities (43) compared to Indonesia. In the Southeast Asia region, the total number of cases announced by national authorities reached 9,550 confirmed cases and 282 mortalities (CFR: 2.9\%), indicating that Indonesia contributed $48 \%$ in the total number of mortalities resulting from COVID-19 in the region.

\section{4. Discussion}

The number of confirmed cases of COVID-19 globally has exceeded that compared to the severe acute respiratory syndrome (SARS) outbreak of cases in 2003. The country has predicted that COVID-19 would become a more significant pandemic and health risk compared to SARS [19]. As with Indonesia, COVID19 reached 1,528 cases, which also exceeded the number of SARS cases. The number of daily cases in Indonesia was also compared to that of Italy. For instance, as at $20^{\text {th }}$ February 2020, the first confirmed case in Italy was announced as pneumonia, and on $15^{\text {th }}$ March, the number of cases exploded reaching $22,512[20]$.

The increase in confirmed cases in Indonesia has been mainly due to the attitude of the government of the Republic of Indonesia, which downplayed the severity of COVID-19. On the first day that a case of COVID-19 was announced, the Health Minister of the Republic of Indonesia mentioned that COVID-19 was just like the flu [21]. Interestingly, WHO had pre-warned Indonesia about the spreading of the disease and called upon Indonesia to declare a national emergency related to COVID-19. In preventing the spreading of COVID-19, Indonesia has introduced several interventions. As at 13th March 2020, the Indonesia President issued decree number 7, regarding the establishment of a task force to accelerate the handling and spread of COVID-19. The Task Force aims to: (1) increase national resilience in the health sector; (2) accelerate the handling of COVID-19 through synergy between ministries/institutions and regional governments; (3) increase anticipation of escalation developments and the spread of COVID-19; (4) increase the synergy of policymaking operationally; and (5) increase the readiness and proficiency in preventing, detecting and responding to COVID-19 [22].

However, at present, the task force has been unable to synergise ministries and government agencies. Likewise, inadequate interventions from the government such as the implementation of physical distancing rules have not been appropriately implemented nor enforced, still allowing mass gatherings 
and mass transport leading to the predictions made by various scientists and public health experts that there will be a further explosion or second wave of COVID-19. Djalante et al. provide several recommendations such tracing the close proximity of people and patient contact, establishing and coordinating polymerase chain reaction laboratories, rapid test detection, increasing the number of referral hospitals, mass spraying of disinfectants, improving health infrastructure, and the need to mainstream the one health approach [23].

Furthermore, some of the considerations that have been taken on board by the Indonesian government included the issues surrounding large clusters related to the spread of COVID-19 and traditional and modern market clusters (i.e. wet markets), Tabligh worshipers in large gatherings in Gowa, Christians in large gatherings in Bogor, and economic seminar clusters prior to the first COVID-19 case in Indonesia being announced. In the current study, we recommend to the Indonesian government to increase the availability and accessibility of ventilators in hospitals in anticipation of a significant increase in cases (i.e. second wave), restrict activities involving large gatherings of people, introduce strict protocols for foreigners and Indonesian citizens travelling back to Indonesia, introduce border controls (red and green zones) for COVID particularly in rural areas and review existing policies related to mass transportation to prevent an upsurge in the number of cases in minimising the number of fatalities.

There are several limitations inherent in this study. The first limitation concerns the data related to age and gender obtained from NGOs amounting to 459 cases and secondly, limited access to the distribution of mortalities by age, gender and comorbidity. However, this does not downplay the significance of this study since it describes the general situation of COVID-19 in the context of Indonesia.

\section{Conclusion}

In Indonesia, between the $2^{\text {nd }}$ and $31^{\text {st }}$ of March 2020, a total of 1,528 patients were diagnosed to be positive with COVID-19. The virus was commonly found in people aged between 31 and 70 years in a higher number of male patients compared to female patients. The CFR of Indonesia is the highest in the Southeast Asia region and the second-highest globally. Given the high fatality rate in COVID-19 cases, the Indonesian government should improve healthcare facilities such as hospitals and clinics by introducing appropriate interventions and other measures to prevent the spread of COVID-19. 
Page 8 of 16

1 Author Contributions: A. Bakar and V. Ningrum conceived and designed the work, A. Bakar and T.I.

2 Kuncoroaji collected the data, S.C. Lee and A. Lee verified the analytical methods, A. Bakar and V.

3 Ningrum organised the paper, and A. Bakar and T.I. Kuncoroaji analysed the findings of this work. All

4 authors discussed the results and contributed to the final manuscript.

5 Conflicts of Interest: We declare there are no competing nor conflicting interests.

6 Acknowledgement: We thank the Indonesian government for providing the open-source data of COVID-

$7 \quad 19$ and non-government organisation volunteers (kawalcovid19.id).

\section{References}

9 1. Huang, C.; Wang, Y.; Li, X.; Ren, L.; Zhao, J.; Hu, Y.; Zhang, L.; Fan, G.; Xu, J.; Gu, X.; et al.

2. WHO Coronavirus disease 2019 (COVID-19) Situation Report-68; 2020;

3. Wu, Z.; McGoogan, J.M. Characteristics of and Important Lessons from the Coronavirus Disease 2019 (COVID-19) Outbreak in China: Summary of a Report of 72314 Cases from the Chinese Center for Disease Control and Prevention. JAMA - J. Am. Med. Assoc. 2020.

4. Onder, G.; Rezza, G.; Brusaferro, S. Case-Fatality Rate and Characteristics of Patients Dying in Relation to COVID-19 in Italy. JAMA - J. Am. Med. Assoc. 2020.

5. Chen, N.; Zhou, M.; Dong, X.; Qu, J.; Gong, F.; Han, Y.; Qiu, Y.; Wang, J.; Liu, Y.; Wei, Y.; et al. Epidemiological and clinical characteristics of 99 cases of 2019 novel coronavirus pneumonia in Wuhan, China: a descriptive study. Lancet 2020.

6. Chan, J.F.W.; Yuan, S.; Kok, K.H.; To, K.K.W.; Chu, H.; Yang, J.; Xing, F.; Liu, J.; Yip, C.C.Y.; Poon, R.W.S.; et al. A familial cluster of pneumonia associated with the 2019 novel coronavirus indicating person-to-person transmission: a study of a family cluster. Lancet $\mathbf{2 0 2 0 .}$

8. Li, Q.; Guan, X.; Wu, P.; Wang, X.; Zhou, L.; Tong, Y.; Ren, R.; Leung, K.S.M.; Lau, E.H.Y.; Wong, J.Y.; et al. Early Transmission Dynamics in Wuhan, China, of Novel Coronavirus-Infected 
Page 9 of 16

\section{Pneumonia. N. Engl. J. Med. 2020.}

9. Wang, D.; Hu, B.; Hu, C.; Zhu, F.; Liu, X.; Zhang, J.; Wang, B.; Xiang, H.; Cheng, Z.; Xiong, Y.; et al. Clinical Characteristics of 138 Hospitalized Patients with 2019 Novel Coronavirus-Infected Pneumonia in Wuhan, China. JAMA - J. Am. Med. Assoc. 2020.

10. He, F.; Deng, Y.; Li, W. Coronavirus Disease 2019 (COVID-19): What we know? J. Med. Virol. 2020.

11. Imai, N.; Cori, A.; Dorigatti, I.; Baguelin, M.; Donnelly, C.A.; Riley, S.; Ferguson, N.M. Report 3: Transmissibility of 2019-nCoV. Imp. Coll. London 2020.

12. How come Indonesia has no Covid-19 cases?: Jakarta Post 2020.

13. Sijabat, D.M.; Paddock, R.C. Indonesia Has No Reported Coronavirus Cases. Is That the Whole Picture? Feb 112020.

14. Gugus Tugas Percepatan Penanganan COVID-19 Situasi virus corona Available online: https://www.covid19.go.id/situasi-virus-corona/ (accessed on Apr 19, 2020).

15. DISKOMINFOTIK Provinsi DKI Jakarta Peta sebaran kasus COVID-19 di Jakarta Available online: https://corona.jakarta.go.id/id/peta-kasus (accessed on Mar 31, 2020).

16. Pemerintah Provinsi Banten Peta Sebaran Covid-19 Provinsi Banten Available online: infocorona.bantenprov.go.id (accessed on Mar 31, 2020).

17. Pusat informasi dan koordinasi Provinsi Jawa Barat Angka Kejadian di Jawa Barat: Peta titik sebaran kasus Available online: https://pikobar.jabarprov.go.id/ (accessed on Mar 31, 2020).

18. Kawal informasi seputar COVID-19 secara tepat dan akurat Available online: kawalcovid19.id (accessed on Mar 31, 2020).

19. Liu, T.; Hu, J.; Kang, M.; Lin, L.; Zhong, H.; Xiao, J.; He, G.; Song, T.; Huang, Q.; Rong, Z.; et al. Transmission Dynamics of 2019 Novel Coronavirus (2019-nCoV). SSRN Electron. J. 2020.

20. Livingston, E.; Bucher, K. Coronavirus Disease 2019 (COVID-19) in Italy. JAMA 2020.

21. Ramadhan, A.; Meiliana, D. Heran Virus Corona Bikin Heboh, Menkes: Batuk Pilek Angka Kematiannya Lebih Tinggi Available online: 
1

2

3

4

5

6

https://nasional.kompas.com/read/2020/03/02/20040881/heran-virus-corona-bikin-heboh-menkesbatuk-pilek-angka-kematiannya-lebih (accessed on Mar 31, 2020).

22. Indonesia, P.R. Keputusan Presiden Republik Indonesia Nomor 7 Tahun 2020 tentang Gugus Tugas Percepatan Penanganan Corona Virus Disease 2019 (COVID-19); 2019; Vol. 2019, pp. $1-8$;

23. Djalante, R.; Lassa, J.; Setiamarga, D.; Mahfud, C.; Sudjatma, A.; Indrawan, M.; Haryanto, B.; Sinapoy, M.S.; Rafliana, I.; Djalante, S.; et al. Review and analysis of current responses to COVID-19 in Indonesia: Period of January to March 2020. Prog. Disaster Sci. 2020.

.

10

11

2

3

4

5

16

17

8

9

0

1

2

3

4

5

6
7 8 
1

2 Figures Legends

3 Figure 1. COVID-19 daily cases, recovery and deaths in Indonesia during March 2020

4 Figure 2. COVID-19 distribution cases in Indonesia

5 Figure 3. COVID-19 distribution cases in Java Island

6

7

8

9

10

11

12

13

14

15

16

17

18

19

20

21

22

23

24

25 


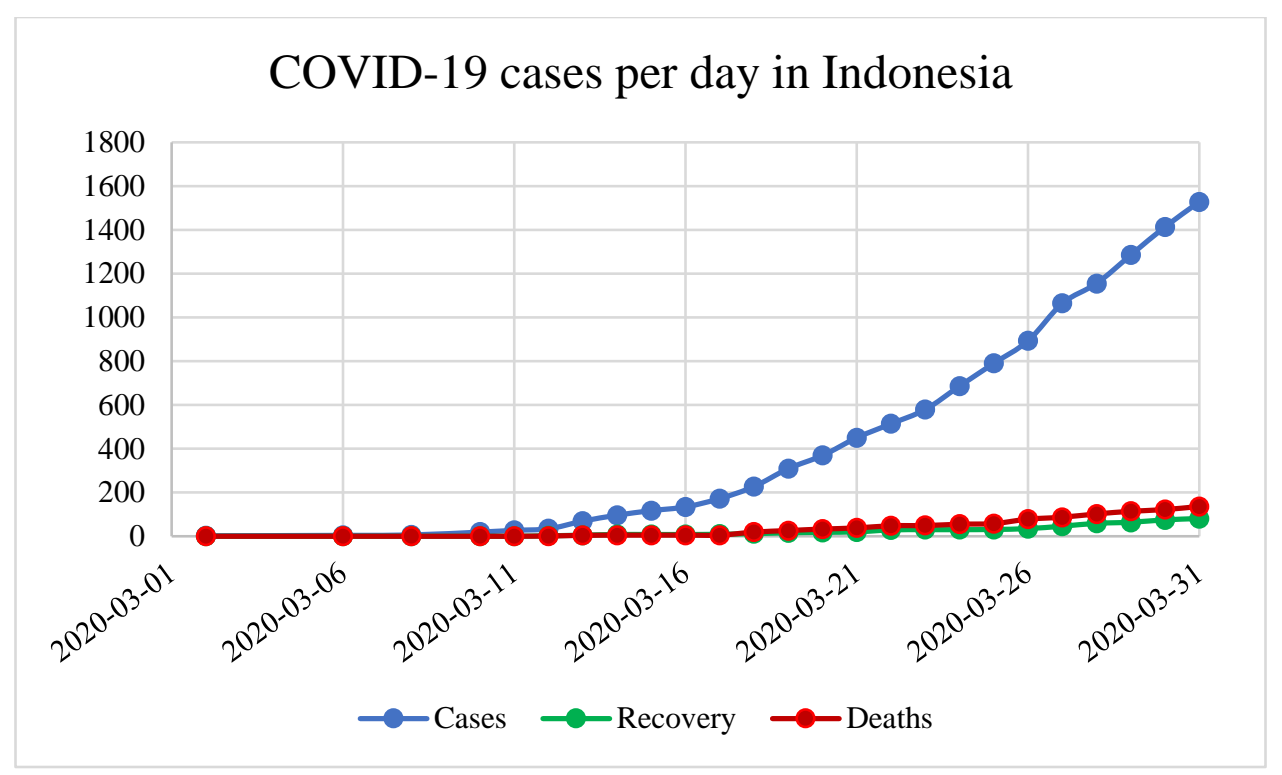

2 Figure 1. COVID-19 daily cases, recovery and deaths in Indonesia during March 2020

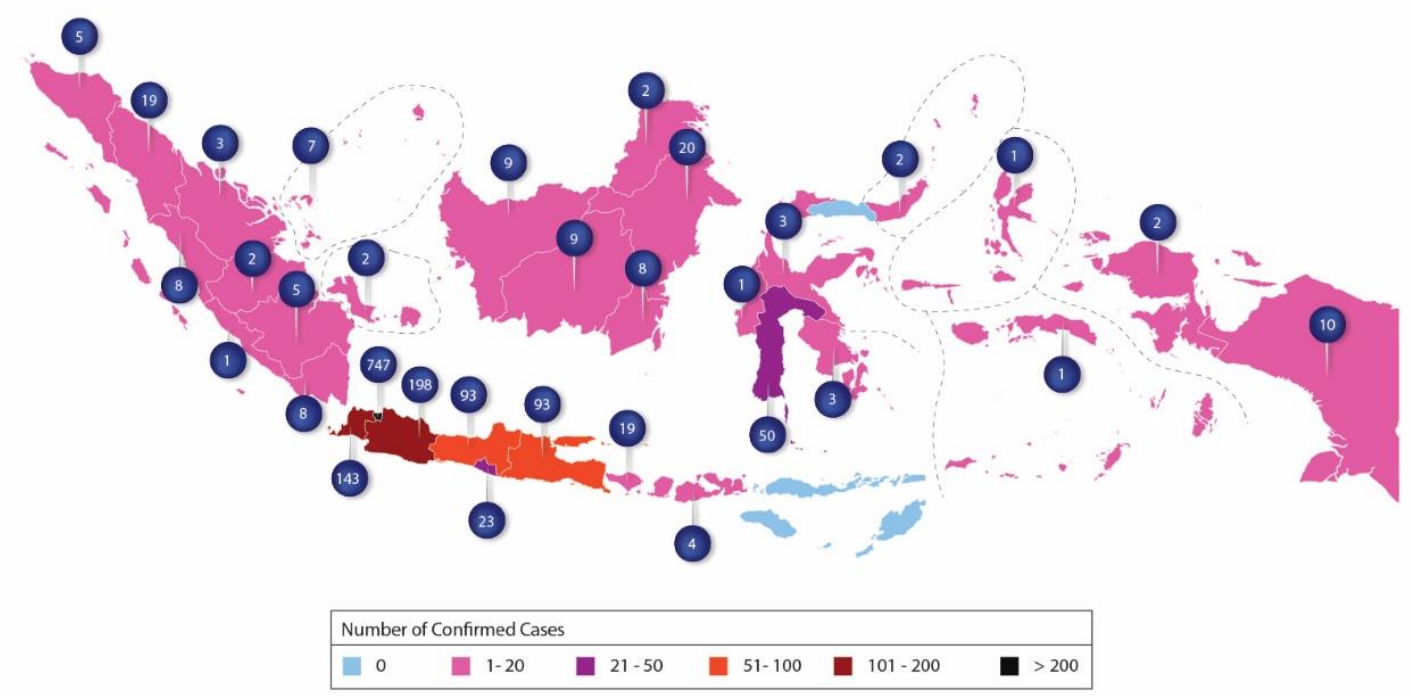

4

8

9 


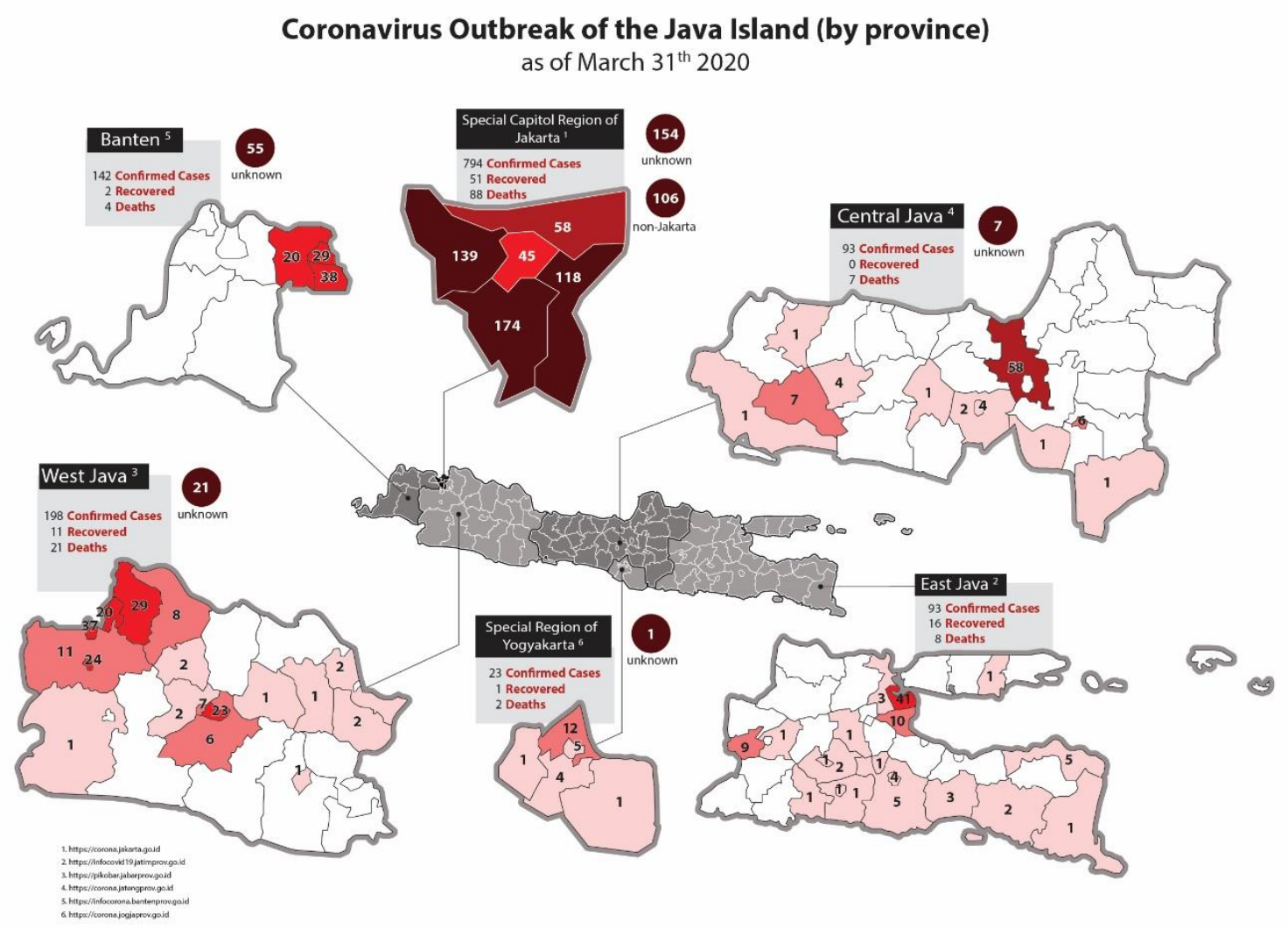

1

Figure 3. COVID-19 distribution cases in Java Island

3

Covid 19 Distribution Based on Age And Gender

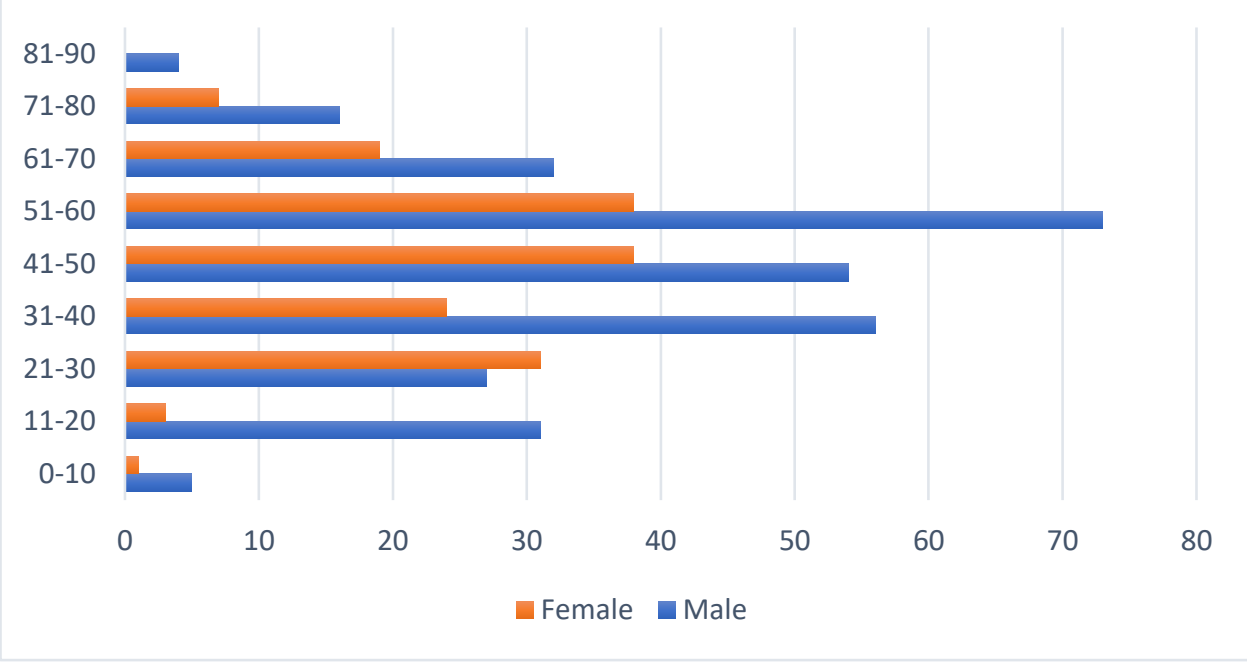

5 Figure 4. COVID 19 distribution based on Age and Gender (Data source from kawalcovid19.id) 
1 Tables.

2 Table 1. Number of cases in Indonesia by age distribution

3 Table 2. Number of cases, recovery, death cases, hospital number, and ventilators number in Indonesia by 4 province.

5

6

7

8

9

10

11

12

13

14

15

16

17

18

19

20

21

22

23

24

25

26

27

28

29

30 
1 Table 1. Number of cases in Indonesia by age distribution

\begin{tabular}{lccccc} 
& \multicolumn{2}{c}{ Official } & \multicolumn{3}{c}{ Kawalcovid19.id } \\
\hline Age & Cases & Percentage & Age & Cases & Percentage \\
\hline & & & $0-10$ & 6 & 1.3 \\
\hline$<20$ & 4 & 5.7 & $11-20$ & 34 & 7.4 \\
\hline $20-29$ & 18 & 11.5 & $21-30$ & 58 & 12.6 \\
\hline $30-39$ & 15 & 21.7 & $31-40$ & 80 & 17.4 \\
\hline & & & $41-50$ & 92 & 20.0 \\
\hline $40-59$ & 31 & 44.9 & $51-60$ & 111 & 24.2 \\
\hline$>59$ & 11 & 15.9 & $61-70$ & 51 & 11.1 \\
\hline & & & $71-80$ & 23 & 5.0 \\
\hline & & & $>80$ & 4 & 0.8 \\
\hline Total & $\mathbf{7 9}$ & & Total & $\mathbf{4 5 9}$ &
\end{tabular}

2

3

4

5

6

7

8

9

10

11

12

13

14

15

16

17

18

19

20

21

22

23 
1 Table 2. Number of cases, recovery, death cases, hospital number, and ventilators number in Indonesia by 2 province.

\begin{tabular}{|c|c|c|c|c|c|c|}
\hline Province & Cases & Recov & Death & CFR & $\begin{array}{r}\text { Hospitals } \\
\text { number }\end{array}$ & $\begin{array}{r}\text { Ventilators } \\
\text { number }\end{array}$ \\
\hline Jakarta & 747 & 48 & 83 & $11.1 \%$ & 144 & 1071 \\
\hline West Java & 198 & 11 & 21 & $10.6 \%$ & 271 & 1214 \\
\hline Banten & 142 & 2 & 4 & $2.8 \%$ & 73 & 323 \\
\hline Central Java & 93 & 0 & 7 & $7.5 \%$ & 186 & 1154 \\
\hline East Java & 93 & 16 & 8 & $8.6 \%$ & 229 & 942 \\
\hline South Sulawesi & 50 & 0 & 1 & $2.0 \%$ & 65 & 289 \\
\hline In investigation & 28 & 0 & 0 & $0 \%$ & & \\
\hline Yogyakarta & 23 & 1 & 2 & $8.7 \%$ & 33 & 238 \\
\hline East Kalimantan & 20 & 0 & 0 & $0 \%$ & 31 & 114 \\
\hline Bali & 19 & 0 & 2 & $10.5 \%$ & 51 & 226 \\
\hline North Sumatra & 19 & 0 & 1 & $5.3 \%$ & 120 & 479 \\
\hline Papua & 10 & 0 & 0 & $0 \%$ & 22 & 45 \\
\hline West Kalimantan & 9 & 0 & 0 & $0 \%$ & 31 & 143 \\
\hline Central Kalimantan & 9 & 2 & 0 & $0 \%$ & 71 & 53 \\
\hline South Kalimantan & 8 & 0 & 2 & $25 \%$ & 28 & 114 \\
\hline Lampung & 8 & 0 & 0 & $0 \%$ & 39 & 91 \\
\hline West Sumatera & 8 & 0 & 0 & $0 \%$ & 42 & 206 \\
\hline Riau Islands & 7 & 0 & 1 & $14.3 \%$ & 24 & 108 \\
\hline Aceh & 5 & 0 & 0 & $0 \%$ & 43 & 139 \\
\hline South Sumatera & 5 & 0 & 2 & $40 \%$ & 55 & 281 \\
\hline West Nusa Tenggara & 4 & 0 & 0 & $0 \%$ & 17 & 121 \\
\hline Riau & 3 & 0 & 0 & $0 \%$ & 43 & 139 \\
\hline Central Sulawesi & 3 & 0 & 0 & $0 \%$ & 27 & 80 \\
\hline Southeast Sulawesi & 3 & 0 & 0 & $0 \%$ & 20 & 68 \\
\hline Jambi & 2 & 0 & 0 & $0 \%$ & 28 & 87 \\
\hline North Kalimantan & 2 & 0 & 0 & $0 \%$ & 6 & 56 \\
\hline $\begin{array}{l}\text { Bangka Belitung } \\
\text { Islands }\end{array}$ & 2 & 0 & 0 & $0 \%$ & 15 & 113 \\
\hline West Papua & 2 & 0 & 1 & $50 \%$ & 8 & 31 \\
\hline North Sulawesi & 2 & 1 & 0 & $0 \%$ & 27 & 83 \\
\hline Bengkulu & 1 & 0 & 1 & $100 \%$ & 14 & 66 \\
\hline Maluku & 1 & 0 & 0 & $0 \%$ & 12 & 22 \\
\hline North Maluku & 1 & 0 & 0 & $0 \%$ & 9 & 39 \\
\hline West Sulawesi & 1 & 0 & 0 & $0 \%$ & 8 & 63 \\
\hline East Nusa Tenggara & 0 & 0 & 0 & $0 \%$ & 25 & 80 \\
\hline Gorontalo & 0 & 0 & 0 & $0 \%$ & 10 & 41 \\
\hline Total & 1528 & 81 & 136 & $8.9 \%$ & 859 & 3326 \\
\hline
\end{tabular}

